\title{
FREIRE E O USO PEDAGÓGICO DA IMAGEM VISUAL NA ALFABETIZAÇÃO DE JOVENS E ADULTOS
}

\author{
Erenildo João Carlos ${ }^{1}$ \\ Raquel Rocha Villar de Alcantara ${ }^{2}$
}

\begin{abstract}
Resumo
Este ensaio cumpre duas funções. A primeira consiste em analisar a ordem do discurso que faz emergir o uso da imagem no processo de alfabetização presente na proposta pedagógica freireana. A segunda, ao mesmo tempo em que opera com a abordagem teórico-metodológica da Análise Arqueológica do Discurso - AAD, proposta por Michel Foucault, visa afirmar que a AAD se caracteriza como uma possibilidade de investigação no campo da educação, especificamente, da educação popular. Constatamos que o enunciado do uso pedagógico da imagem aparece em menções sobre os gêneros do desenho pictórico, fotográfico e audiovisual. O emprego de imagens visuais está relacionado às noções de código visual, representação de mundo e objeto de conhecimento e às funções de associação mnemônica, ilustração e mediação do conhecimento como estratégias pedagógicas da alfabetização de jovens e adultos. O estudo assinala, de um lado, a pertinência teórico-metodológica da AAD e, de outro, que, embora Freire não tenha desenvolvido uma discussão elaborada, a problemática da imagem visual não deixou de ser objeto de sua atenção e utilização na prática educativa.
\end{abstract}

Palavras-chave: Alfabetização de Jovens e Adultos; Imagem Visual; Análise Arqueológica do Discurso

\footnotetext{
1 Pedagogo, Doutor (UFC) e mestre (UFPB) em educação. Professor do Curso de Graduação em Pedagogia e do Programa de Pós-Graduação em Educação (PPGE) do Centro de Educação (CE) da Universidade Federal da Paraíba (UFPB). Atualmente, lotado no Departamento de Fundamentação da Educação (DFE). E líder do Grupo de Estudo e Pesquisa em Educação de Jovens e Adultos (GEPEJA), vinculado a Linha de Pesquisa Educação Popular, do PPGE/UFPB. E-mail: erenildojc@hotmail.com

${ }^{2}$ Pedagoga e mestranda (UFPB) em educação do Programa de Pós-Graduação em Educação (PPGE) do Centro de Educação (CE) da Universidade Federal da Paraíba (UFPB). Integra o Grupo de Estudos e Pesquisas em Educação de Jovens e Adultos (GEPEJA), vinculado a Linha de Pesquisa Educação Popular, do PPGE/UFPB. Email: keldealcantara@gmail.com
} 


\section{INTRODUÇÃO}

O título deste texto representa uma síntese de múltiplas determinações específicas do objeto de interesse deste ensaio. Essas determinações são sinalizadas nos elementos singulares registrados na própria frase que materializa gramaticalmente o enunciado, como as expressões "Paulo Freire", “uso pedagógico", "imagem visual", "alfabetização de jovens e adultos" e, evidentemente, as possíveis relações existentes entre os elementos postos na assertiva que nomeia e intitula o texto. Cada determinação se caracteriza como ponto de questionamento, como eixo articulador da reflexão, como via de provocação da curiosidade e dispositivo desencadeador da vontade de saber do leitor, cuja centralidade, de um ou de outro aspecto, poderá ativar os demais elementos do campo enunciativo, movê-los, ligá-los, cindi-los, evidenciá-los, exaltá-los, afirmá-los, conferir-lhes visibilidade e status, ou, simplesmente, silenciá-los, negá-los, marginalizá-los, desprestigiá-los e excluí-los.

Não pretendemos discutir sobre todas as determinações indicadas anteriormente, pois elas desenham um horizonte amplo de investigação, cuja realização, aqui, apenas se anuncia e se esboça. Nesse momento, nosso interesse e desejo são mais modestos. Apontamos várias determinações somente como norte para nos situarmos no horizonte que ora vislumbramos. Elas cumprem uma função gnosiológica. Como diria o próprio Freire, são empregadas tãosomente como temas geradores, que desencadeiam nossa reflexão e abrem alternativas de problematização de algumas determinações que constituem o objeto de nosso interesse.

\section{EXPLICITANDO O PERCURSO DA REFLEXÃO}

Podemos dizer que, embora não esteja evidente no título, o tratamento conferido à questão do uso pedagógico da imagem visual em Freire caracteriza-se como uma determinação, pois funciona como uma espécie de dispositivo de produção do processo analítico-argumentativo que resultou na formulação anunciada. Por isso, entendemos que o percurso trilhado no desenvolvimento de nossa reflexão seja uma das dimensões fundamentais das condições de existência do enunciado "Paulo Freire e o uso pedagógico da imagem visual na alfabetização de jovens e adultos".

O dispositivo de análise que tece a feitura do título e dos argumentos apresentados aqui inspira-se, pelo menos, em três domínios do saber: o de Platão (2001), propiciado pelo diálogo registrado no Crátilo; o de Ferdinando Saussure (2006), iluminado pela noção tricotômica de signo apresentada no livro Curso de Linguística Geral; e o de Foucault (1999), 
proporcionado pelo legado que nos deixou sobre as epistemes que marcaram a vontade de saber do mundo ocidental, presentes no livro As palavras e as coisas.

O Crátilo de Platão é um diálogo belíssimo, supostamente realizado há mais de dois mil anos, na Grécia, entre Hermógenes, Crátilo e Sócrates sobre o território da linguagem, ou, mais especificamente, sobre a natureza dos nomes e suas funções. Conversando sobre o assunto, Hermógenes interpelou Sócrates para elucidar a questão, porque Crátilo entendia que haveria uma identidade entre a natureza dos nomes e as coisas que eles designam, ou seja, “[...] que cada um dos seres tem um nome que lhe pertence por natureza e que não é nome aquilo a que alguns chamam nome [...]” (PLATÃO, 2001, p.43), e ele, diferentemente, considerava que os nomes seriam apenas uma representação simbólica das coisas, estabelecida por convenção social, porque entendia que “[...] nenhum nome pertence, por natureza, a nenhuma coisa, mas é estabelecido por lei e pelo costume daqueles que usam chamando as coisas [...]” (PLATÃO, 2001, p. 44). Interrogado e aceitando o desafio, Sócrates respondeu a Hermógenes reflexivamente, dizendo: “[...] é difícil conhecer as coisas, pelo que é necessário que as investiguemos percorrendo juntos os argumentos, para ver se é como tu dizes ou como diz Crátilo [...]" (PLATÃO, 2001, p. 44).

No universo rico de informações e de argumentos que encontramos nas oitenta e duas páginas da tradução que lemos, cabe assinalar a ideia de que o diálogo entre Hermógenes, Crátilo e Sócrates guarda uma dimensão metodológica cujos protagonistas da conversa põem em jogo a existência das coisas, das palavras e das possibilidades de relações que podem ser estabelecidas entre elas. Esses três aspectos do diálogo socrático são significativos para o dispositivo de análise com o qual operamos, porque ele aponta, de um lado, o reconhecimento da existência de cada uma dessas dimensões e, de outro, que cada uma delas existe de maneira diferente. Assim, as coisas nos remetem ao chão da realidade da experiência; os nomes ou palavras, ao terreno da linguagem; e as possíveis relações, ao nível arqueológico das relações enunciativas do discurso.

Se o diálogo socrático se apresenta como uma fonte de inspiração para organizar o percurso analítico-reflexivo de nossa investigação, podemos dizer o mesmo em relação aos estudos de Ferdinando Saussure (2006) e ao tratamento que decidiu assumir no que tange às suas investigações no território da linguagem. Referimo-nos, aqui, especificamente, à noção tricotômica de signo, apresentada no livro Curso de Linguística Geral, composta pelo significante (marca), pelo significado (ideia) e pela referência (aquilo sobre o que se diz algo).

Essa noção de signo contém um componente metodológico interessante, pois, se, no Crátilo de Platão, as relações entres esses três aspectos do signo não se encontravam 
explicitamente organizadas em um formato tricotômico, em Saussure, encontramos essa estrutura apresentada como um modo de existir da própria linguagem. Assim, a noção tricotômica de signo, em Saussure, por constituir o próprio ser da linguagem, aparece como um conceito-chave para se entender a inteligibilidade da estrutura e do funcionamento da língua, portanto, como um dispositivo de análise, de escavação, de descrição e de explicitação do ser da linguagem em geral.

Essas questões também foram estudadas em pesquisas feitas por Foucault (1999), cujas anotações foram publicadas no livro As palavras e as coisas. Embora, nessa publicação, Foucault tenha se ocupado em investigar o modo de produção do saber dominante em determinados períodos da história do Ocidente, encontramos a discussão sobre a relação entre as palavras e as coisas tecidas a partir de uma perspectiva própria, que ele mesmo nomeou em outro lugar de "arqueologia do saber".

Devido ao significativo volume de informações registrado por Foucault nesse livro, interessa-nos assinalar tão somente o fato de seu escrito indicar o que poderíamos chamar de "giro arqueológico". Ou seja, ao analisar a problemática do saber, Foucault acaba por escavar o terreno da linguagem. No curso dessa escavação, para analisar a inteligibilidade dos saberes e seus modos de produção antiga, clássica e moderna, Foucault deparou-se com a presença do signo e, consequentemente, com seu modo de existência tricotômico e suas funções clássicas (representação) e modernas (significação) efetivadas no âmbito da relação entre as palavras e as coisas, e constatou o fato de que o saber se vincula à questão do discurso. Portanto, para além das palavras e das coisas, existe o discurso funcionando como uma prática relevante na produção do saber. Sobre a emergência do discurso, Foucault (1999, p. 59) assevera:

[...] A profunda interdependência da linguagem e do mundo se acha desfeita. $\mathrm{O}$ primado da escrita está desfeito. Desaparece então essa camada uniforme onde se entrecruzavam indefinidamente o visto e o lido, o visível e o enunciável. As coisas e as palavras vão separar-se. O olho será destinado a ver e somente a ver; o ouvido somente a ouvir. O discurso terá realmente por tarefa dizer o que é, mas não será nada mais que o que ele diz.

Conforme o estudo empreendido, Foucault constatou que saber e discurso estão implicados no ponto de que seria inevitável dizer que o saber que se tem sobre alguma coisa depende, sobretudo, do discurso existente, em que as palavras e as coisas são posicionadas em função do jogo interposto pela ordem discursiva vigente. Nisto consiste o giro arqueológico: parte-se da escrita do mundo, passa-se pelo signo como o ser da linguagem e alcança-se o nível próprio da existência do discurso, como prática produtiva do saber, dos significados e 
das representações que eles carregam.

Nessas condições, podemos depreender do Crátilo de Platão, de Saussure e de Foucault, pelo menos, duas ideias operativas. Em primeiro lugar, que cada dimensão e modo particular de existência de cada uma das dimensões da tricotomia comportam uma variedade infinita, porém determinada de objetos, problemas, hipóteses, modos de organizar as informações e os procedimentos de investigação os mais diferentes possíveis. Em segundo, que o processo de investigação, realizado com o rigor metodológico exigido pela natureza dos objetos, dos problemas e das hipóteses levantadas, produzirá um saber específico, relativo e restrito, cuja generalização para as outras dimensões ou campos será sempre problemática, no sentido de querer afirmar-se como o correto, o certo, o verdadeiro e o único, desprestigiando e desqualificando os outros saberes.

\section{ESCAVANDO O CHÃO DA EXPERIÊNCIA}

Nossa familiaridade com temas, objetos, situações, estórias, pessoas, instituições, enfim, com diferentes tipos de lugares, artefatos e práticas culturais efetivamente produzidos faz com que possamos pensar sobre a possibilidade de erigir a experiência como uma fonte de saber. Nesse sentido, entenda-se, aqui, experiência como um termo que nos remete a algo que se realiza, que acontece efetivamente no cotidiano e na história. ${ }^{3}$ Nessa perspectiva, emerge a hipótese de que, em certa medida, só sabemos quando vivemos uma experiência, ou seja, quando estabelecemos com determinados acontecimentos uma relação direta, a partir da qual aprendemos algo. Em tais condições, o saber aprendido e construído, bem como a vivência efetiva dos acontecimentos seriam dois aspectos de um mesmo circuito gnosiológico, no qual a vivência seria o fundamento do saber.

Ao pressuposto do saber de experiência associam-se duas premissas. A primeira, pertinente às relações intersubjetivas relativas à comunicação. Nesse caso, pode-se dizer que a narrativa do vivido aparece entrelaçada ao saber de experiência porque aquela exerceria a função estratégica de disseminação do saber. Assim, o relato seria o recurso, por excelência, através do qual o saber de experiência seria comunicado. Essa seria uma das razões pelas quais, por exemplo, a cultura oral se manteria viva. Nesse processo, ver e ouvir são dois tipos de ações essenciais ao modus operandi das práticas culturais orais que visam efetivar a

\footnotetext{
${ }^{3}$ Embora assumamos esse entendimento de experiência na ordem geral de nossa argumentação, sabemos que existe uma diversidade de possibilidades de significado para o termo. A título de curiosidade, sugerimos a leitura do seguinte texto: Amatuzzi, M. (2007). Experiência: um termo chave para a Psicologia. Memorandum,13, 08-15. Disponível em http://www.fafich.ufmg.br/memorandum/a13/amatuzzi05-pdf/. Acesso em: 08 abr. 2017.
} 
produção, a transmissão e a apropriação social dos saberes de experiência, tidos como legítimos.

A segunda premissa relaciona-se ao princípio da realidade do conteúdo narrado. Nesse caso, o pressuposto é o de que as coisas que se dizem sobre algo, em uma narrativa qualquer, requerem que o que seja comunicado tenha sido vivido, seja pelo narrador, seja por outros. Assim, a vivência carrega uma conotação de que o acontecimento de fato tenha ocorrido. Em outras palavras, a narrativa não somente informa o ocorrido, como também o afirma, confirmando sua realidade e atualidade na memória social. Pode-se dizer que essa premissa regularia até mesmo as narrativas de caráter mítico e místico, cujo anúncio deve ser revestido do sentido de veracidade devido à sua realidade. Entendemos que aqui residiriam sua força e seu poder de convencimento. Em outras palavras, o relato de experiência deve ser capaz de convencer seu ouvinte ou leitor acerca da realidade do conteúdo narrado e da veracidade de sua mensagem.

Ora, se o saber de experiência requer a familiaridade dos assuntos tratados, portanto, a imersão do sujeito no seio da realidade imediata em que o tema se cristalizasse e, se, concomitantemente, o objeto narrado devesse ser, necessariamente, um aspecto constituinte do mundo real, deparamo-nos com uma situação gnosiológica, cujo circuito experiênciasaber-narrativa apontaria uma limitação sobre sua possibilidade efetiva de garantir a certeza da realidade e, consequentemente, da veracidade do conteúdo narrado, portanto, da própria credibilidade da narrativa como um dispositivo de pronunciamento do mundo real.

Um dos efeitos dessa dúvida seria o aparecimento do questionamento acerca da veracidade ou falsidade da realidade ou fantasia do relato e de seu conteúdo. Em outras palavras, a exigência do critério da experiência e da vivência efetiva dos acontecimentos narrados faz aparecer a necessidade da problematização concomitante dos elementos constituintes do circuito experiência-saber-narrativa, tendo em vista a verificação de sua realidade ou não. Nesse processo, a problematização emerge não somente como um dispositivo de produção do saber de experiência, mas também como uma via de verificação de sua veracidade, ensejando, assim, a possibilidade da emergência do circuito gnosiológico assentado na trilogia experiência-problematização-narrativa.

Transitando no campo dessa contradição, ao acolher, em certa medida, os pressupostos anteriores, assim como o reconhecimento da dúvida, tornou-se lugar comum, no seio do campo da Educação Popular, a necessidade do dispositivo reflexivo de problematizar o caráter realista das experiências vividas e de seus efeitos sobre a formação da consciência da subjetividade dos indivíduos e da opinião pública. Dessa maneira, as noções de realidade, de 
experiência e de vivência funcionam como princípios orientadores do pensar crítico imerso na imediaticidade do mundo e nas situações-problema cotidianas.

No horizonte da atuação efetiva da Educação Popular (EP), como prática educativa singular, a realidade é o ponto de partida e de chegada do pensamento e da prática reflexiva e transformadora da natureza, da cultura e da sociedade. Nesse processo, é comum, por exemplo, a EP trabalhar com o conceito de práxis $^{4}$, cujo significado filosófico pressupõe a articulação dialética entre o pensamento e a ação, a teoria e a prática, o discurso e sua realização.

Quanto ao pensar crítico-reflexivo no campo da produção do saber elaborado sobre a realidade, os referidos pressupostos desencadeiam o exame criterioso e cuidadoso de questões de natureza teórica ou prática, fundamentado em referências teórico-metodológicas que estejam mais afeitas ao horizonte de luta e de engajamento dos educadores, dos militantes e dos pesquisadores populares. Nessa condição, tornou-se regular a utilização de procedimentos de investigação peculiares, como, por exemplo, a denominada "sistematização da experiência", cujo dispositivo exige um grau de rigor metódico no processo de análise, registro e comunicação do objeto de interesse da investigação.

Nota-se que o campo de possibilidade ensejado por essas alternativas de produção do saber, cujo pressuposto articula experiência, problematização e narrativa, alcança um grau de refinamento mais acentuado na medida em que assume um horizonte de trabalho alinhado à dimensão da pesquisa científica. Assim, os componentes do circuito gnosiológico experiência-saber-narrativa podem ser tratados como objetos distintos e separados ou concomitantes, em diferentes tipos de pesquisa e acabam sendo aperfeiçoados e desenvolvidos como dispositivos metodológicos, com os quais se operam a coleta de dados, a organização das informações, a escolha das fontes e os mecanismos de análise e de tratamento das informações.

Exemplo disso pode ser ilustrado com a pesquisa realizada por Carvalho (2004), Políticas para a Educação e a Cultura do Governo Aluízio Alves - 1961-1964. Durante a análise das fontes documentais, o pesquisador se deparou com a conhecida "Experiência de Angicos", considerada uma das ações da política educacional realizada pelo estado do Rio Grande do Norte em 1963. Devido à relevância desse achado, no contexto geral de sua

\footnotetext{
${ }^{4}$ Para se aprofundar mais, ler: VAZQUES, Adolfo Sanchez. Filosofia da Práxis. Trad. Luiz Fernando Cardoso. 4. ed., Rio de Janeiro: Editora Paz e Terra, 1977.

${ }^{5}$ Sobre isso, consultar HOLLIDAY, Oscar Jara. Para sistematizar experiências. Tradução de Maria Viviana V. Rezende. João Pessoa: Editora Universitária/UFPB, 1995.
} 
pesquisa, Carvalho acabou por investigá-la ${ }^{6}$, conforme assinala:

[...] as fontes me levaram a privilegiar um evento que ficou registrado na história da educação brasileira como a Experiência de Angicos, que pôs em prática o projeto pedagógico de alfabetização de adultos proposto por Paulo Freire, na época - janeiro de 1963, ainda denominado timidamente de "método Paulo Freire". (CARVALHO, 2004, p. 99).

Destacamos que, embora a "experiência de Angicos" não tenha sido o objeto principal de seu interesse de pesquisa, assim como as estratégias de investigação atinentes à problematização e à sistematização, a descoberta casual e o registro ocasional desse achado chamaram a sua atenção e despertaram sua curiosidade e seu interesse. Ao vasculhar essas fontes em busca de mais informações sobre "[...] $\mathrm{O}$ uso de imagens pelo método de alfabetização proposto por Paulo Freire [...]”, Carvalho (2004, p. 99) localizou “[...] a formulação de imagens visuais nas 'fichas' com desenhos das 'palavras geradoras' [...]”, que aponta uma série de "[...] relações entre desenho e palavra e entre esses e as expectativas de sua eficiência no processo ensino-aprendizagem da leitura e da escrita [...].” Analisando esses “[...] dispositivos visuais e imagens, algumas inéditas, de acordo com um método de base iconológica em que concorrem contribuições analíticas de Panofsky (1979) e de Tardy (1976) [...]", concluiu que parte significativa do êxito do método de alfabetização freireano se fundamentava no uso pedagógico da imagem visual.

[...] Próximas de seus referenciais reais, as imagens visuais cumpriam sua função de eficiente artifício mnemônico no sentido da ligação com suas representações verbais gráficas, ainda mais quando estavam cultural e afetivamente associadas ao universo vivencial dos alunos. (CARVALHO, 2004, p.113).

Através da referida pesquisa, queremos frisar o que temos argumentado até aqui: em primeiro lugar, a investigação empreendida por Carvalho constatou, a seu modo, a relevância da experiência, da vivência e do saber como premissas epistemológicas e pedagógicas, fundadoras do modo de pensar e de fazer pedagógico, exitoso e competente, elaborado e aplicado por Paulo Freire, em um processo concreto de alfabetização de jovens e adultos. Tal experiência integra o acervo de saber produzido pela Educação Popular no Brasil e na América Latina.

Em segundo lugar, a pesquisa também demonstra o que temos afirmado sobre a existência de um campo investigativo cujo terreno contempla e sedimenta uma camada rica de

${ }^{6}$ [...] Parte dos resultados do projeto de pesquisa 'Políticas para a Educação e a Cultura do Governo Aluízio Alves - 1961-1964' (p. 99). 
objetos, categorias de análise e fontes imersas na objetividade do solo da experiência, da vivência e do saber, tal como os proporcionados e representados na emblemática "experiência de Angicos", cuja concepção e prática alfabetizadora ele adotou, e o uso da imagem visual como um dos pilares da mediação eficiente da aprendizagem da lecto escrita e da formação da consciência crítica de alfabetizandos jovens e adultos.

\section{MAPEANDO SIGNIFICANTES E SIGNIFICADOS}

Deslocando-se do mundo fático da experiência e da vivência e, consequentemente, do jogo das narrativas vinculantes, o estudioso ou pesquisador situado no território da linguagem não mais estará preocupado e ocupado em verificar se as narrativas e os relatos de pesquisas correspondem à realidade dos fatos nem irá mais operar com a noção verdade como representação da realidade objetiva. Mas, irá analisar e explicitar, seja nas narrativas ou nos relatos de pesquisas, seu conteúdo simbólico, ou seja, o modo como os sujeitos e os documentos significam as coisas, atribuem sentidos e valoram os acontecimentos e as experiências tratadas. Assim, o foco não se encontra mais nas coisas, mas no significado que elas têm, individual e coletivamente, e não se procura mais nas fontes uma realidade exterior a ela.

Nessas condições, as investigações sobre Paulo Freire podem centrar-se em seus próprios escritos como documentos-fonte de pesquisa, nos relatos de experiência de educadores e militantes que trabalharam ou trabalham com a perspectiva pedagógica freireana. Ou, ainda, em registros escritos, iconográficos e audiovisuais sobre as experiências históricas feitas com o método Paulo Freire, como a que ocorreu em Angicos, no Rio grande do Norte/Brasil, em 1963, e das vividas na América Latina e na África.

Nesse caso, a intenção do pesquisador não seria de verificar se o que foi dito e escrito foi posto em prática, se havia uma coerência entre a proposta e a vivência ou se o discurso era confirmado pela ação. No território da linguagem, orientado pelo critério do par significantesignificado, o estudioso ou pesquisador analisaria o modo como Paulo Freire concebeu e significou as coisas sobre as quais falava, escrevia e se pronunciava, como, por exemplo, a importância ou não que ele conferiu ao uso pedagógico de imagens visuais na alfabetização de jovens e adultos.

Se considerarmos os escritos de Freire como documentos-fonte para examinar o modo como ele concebeu o uso pedagógico da imagem visual na educação de jovens e adultos, provavelmente nos depararemos com essa questão de um modo ou de outro. É bem provável 
que nem todos os textos tratem do assunto. Alguns mais, outros menos. Vários sequer farão menção. Esse resultado poderá ser obtido sem grande esforço analítico. Para isso, basta que se faça um exercício de busca do assunto em seus escritos, através de palavras-chave ou descritores, correlacionados à questão da imagem, como o uso dos significantes "visual", "signo", "visualidade" e "figura", ou dos gêneros visuais clássicos e contemporâneos, como o “desenho", a "pintura", a "fotografia", a "televisão", o "cinema" e a "infoimagem".

De certo modo, Romão (2010) assumiu essa possibilidade de investigação no território da linguagem, escavando a camada do par significante-significado concebido por Freire sobre a noção de imagem, ao escrever o texto Paulo Freire e a Imagem. Além disso, sua análise discutiu sobre a questão inspirando-se em Dabray e debruçando-se em três produções de Freire: Pedagogia do oprimido, Pedagogia da esperança e Pedagogia da autonomia ${ }^{7}$. Sobre isso, ele enuncia: “[...] rastrear na obra de Paulo Freire o termo 'imagem' e, com o levantamento feito, verificar o(s) significado(s) que lhe atribuiu o pensador pernambucano, para concluir sobre a(s) relação(ões) que ele tenha estabelecido entre imagem e educação" (ROMÃO, 2010, p. 79).

Na busca feita a partir do critério de ocorrência da palavra "imagem" e de alguns correlatos, Romão (2010, p. 91) constatou que, em Pedagogia do oprimido, “[...] não há nenhuma ocorrência da palavra 'imagem', mas de seu termo correlato 'visual' e derivados aparecem 12 vezes, mas apenas duas com o sentido que é o foco deste trabalho [...].” $\mathrm{O}$ sentido ao qual se refere Romão (2010, p. 91) diz respeito ao uso prático da imagem nos processos educativos empreendidos por Freire, em que a imagem é empregada "[...] como canal necessário, quando se trata de círculo de cultura com alfabetizandos(as) que ainda não sabem ler a escrita da língua materna [...]." Não obstante o encontro de tal menção correlata, Romão informa também a falta de uma discussão mais aprofundada, no plano teórico, sobre a questão específica da imagem no referido livro. Sobre isso, ele afirma (2010, p. 91):

[...] A pesquisa de vocábulos próximos do termo 'imagem', como 'ícone' (nenhuma ocorrência) e 'signo' (apenas uma ocorrência, em seu sentido mais geral), demonstram que Paulo Freire, em Pedagogia do oprimido não fez uma discussão sobre a gênese da imagem. ( $\mathrm{g}$ grifo é nosso)

Quanto ao texto Pedagogia da esperança, Romão (2010, p. 92) afirma que, “[...] nessa

\footnotetext{
${ }^{7}$ Em nota de rodapé de seu texto, Romão (2010, p. 91) justifica da seguinte maneira a escolha dessas referências freireanas como textos-fonte de sua reflexão sobre a questão da imagem: “[...] Considero como obras principais: Pedagogia do oprimido (1970), Pedagogia da esperança (1992) e Pedagogia da autonomia (1997). A meu juízo, elas são suficientes para a retomada das categorias freireanas."
} 
obra, não há qualquer ocorrência de 'imagem', 'visual', 'ícone', 'iconográfico'. 'Signo' aparece duas vezes, no sentido de símbolos pátrios (a bandeira nacional etc.).” Já em Pedagogia da autonomia, "[...] aparece uma ocorrência do termo "imagem”, mas nenhuma de seus correlatos (visual, ícone, iconográfico etc.)" (ROMÃO, 2010, p.92). Nesse caso, o significante "imagem" é descrito como um suporte relevante tanto quanto são a escrita e a fala para o exercício pleno da "comunicação" e da "inteligência do mundo". Do exposto, conclui Romão (2010, p. 93):

[...] No fundo, a apreensão crítica do mundo e a comunicação do apreendido é a matéria-prima básica do diálogo, uma das principais, se não a mais importante, categorias das pedagogias freireanas. E essa apreensão, pelo que se pode depreender do texto das citações de Pedagogia da autonomia independe da base material (escrita ou não), mas depende, fundamentalmente, da imagem que o ser humano faz do mundo.

Depreendemos do levantamento, das constatações e da argumentação de Romão que, não obstante a verificação de uma recorrência pontual, vinculada ao uso didático da imagem e da falta de uma reflexão elaborada sobre a "gênese da imagem", que Paulo Freire não elidiu a questão. Ou seja, o fato de ter identificado a ocorrência e o modo como abordou o assunto demonstra, para Romão, que Paulo Freire não fez tabula rasa nem foi indiferente à questão da imagem. Nesse sentido, comenta:

[...] examinando as demais obras de Paulo Freire, percebe-se, no conjunto, uma profunda convicção da superioridade da forma de conhecer dos (as) oprimidos (as) por causa da incorporação da Razão Figurativa, ou seja, daquela forma de apreensão do mundo que, para ser crítica, tem de incorporar racionalidade e sensibilidade. (ROMÃO, 2004, p. 95).

Assim, Freire conferiu à imagem um grau significativo de relevância, ao incorporá-la em seu trabalho educativo, usando-a como mediação da aprendizagem da inteligibilidade do mundo. Nesse sentido, Romão entende que Paulo reconheceu a importância da Razão Figurativa como um dispositivo pedagógico de mediação dos processos educativos populares, por compreender que a racionalidade e a sensibilidade dos oprimidos são fundamentalmente visuais.

\section{ESCANDINDO A CAMADA DO DISCURSO}

Com o olhar fixo no horizonte do discurso, vimos que o filósofo e educador 
pernambucano não deixou de tratar o assunto, seja no que tange à discussão que empreendeu sobre a prática educativa, seja no que tange à prática efetiva e específica de operar com a imagem visual no terreno peculiar de suas experiências voltadas para a alfabetização de jovens e adultos. Durante o processo de escavação, identificamos três noções de imagem representação de mundo, código visual e objeto do conhecimento - e três possibilidades de uso - associação mnemônica, ilustrativa e de mediação do conhecimento. $\mathrm{Na}$ ordem do discurso investigado, tanto essas possibilidades de uso quanto as noções de imagem estão atreladas aos seguintes tipos de imagem: desenhos, fotografias, pinturas e audiovisuais.

Quanto às noções, notamos que a "representação de mundo" emerge como um enunciado constitutivo das noções de imagem, presentes no discurso visual mobilizado por Freire em sua proposta pedagógica. Representar o mundo, nessa perspectiva, requer a relação, mobilizada na estrutura do signo, entre o significado, o significante e a referência. Nessa ordem do discurso, para que a imagem possa representar alguma coisa, é preciso que ela faça referência a uma situação concreta, ou seja, existencial, às coisas que realmente existem. As proposições, assertivas ou afirmações que a imagem em questão possibilita que sejam feitas devem estar correlacionadas com uma referência concreta. Enfim, não se trata daquilo que o educando e o educador acreditam ou desejam que seja, pois isso deslocaria a noção para o campo dos significados e sentidos, mas do que é concreto. Por exemplo:

[...] Suponhamos [...] a codificação de uma situação de trabalho no campo. A "estrutura de superfície" dessa codificação seria representada por diferentes dados: a presença de mulheres e de homens trabalhando com alguns instrumentos; a figura do patrão, no seu cavalo; árvores, pássaros, animais etc. O primeiro momento da "leitura" ou descodificação se centra na descrição daqueles dados. "Vemos dois homens e três mulheres trabalhando. O patrão olha eles de seu cavalo. Lá longe tem umas árvores. Tem também uns passarinhos nos galhos. $\mathrm{E}$ animal pastando. $\mathrm{O}$ céu escuro indica chuva" etc. (FREIRE, 1982. p. 51, 52).

Já a noção de "código visual" aparece relacionada à possibilidade de os educandos fazerem leituras das imagens apresentadas como situações existenciais codificadas. A leitura realizada pelos educandos é considerada como um processo de descodificação, de "leitura da leitura". Nessa ordem do discurso, há um deslocamento da representação centrada na referência, para a relação entre o significante (as marcas empírico-visuais) e o significado (as ideias relacionadas ao significante). Essa noção direciona as leituras não às situações concretas, mas a outras leituras que já estão presentes na imagem. Conforme Freire (1982, p. 51), “[...] a codificação, mesmo quando puramente pictórica, é um 'discurso' a ser 'lido' por quem procura decifrá-la. Como tal, apresenta o que Chomsky chama de 'estrutura de 
superfície' e estrutura profunda [...]."

Finalmente, a noção da imagem como objeto do conhecimento foi identificada. Ela se difere da possibilidade de uso como mediadora do conhecimento, pois, nesse caso, não é uma mera estratégia colocada diante do sujeito para que ele acesse um saber ou problematize alguma questão suscitada pela leitura da imagem. Ao contrário, esse enunciado confere status ao caráter de objeto do conhecimento à própria imagem. Por exemplo, em um dos relatos a respeito de experiências educativas em que se usava a imagem, Freire (1967, p. 120) diz:

[...] $\mathrm{Na}$ medida em que os grupos, discutindo, fossem percebendo o que há de engodo na propaganda, por exemplo, de certa marca de cigarros, em que aparece uma bela moça de biquíni, sorridente e feliz (e que ela em si mesma, com seu sorriso, sua beleza e seu biquíni não tem nada que ver com o cigarro), iriam descobrindo, inicialmente, a diferença entre educação e propaganda. Por outro lado, preparando-se para depois discutir e perceber os mesmos engodos na propaganda ideológica ou política. Na sloganização, iriam armando-se criticamente para a 'dissociação de ideias' de Huxley.

A noção de imagem como objeto do conhecimento possibilita a formulação de questões problema e o estabelecimento de hipóteses a respeito da própria imagem, e não, do que ela representa ou intermedeia. O educando é interpelado a formular questões a respeito da imagem, e não, de aspectos exteriores a ela.

Quanto ao uso, o emprego da imagem visual ocorre de várias maneiras. A primeira se efetiva através da "associação mnemônica", pertinente a um discurso presente no campo da cognição e da didática, que aciona elementos como memória, associação e conteúdo. Trata-se de um discurso que, embora não se limite à aprendizagem em uma perspectiva memorística, apresenta uma preocupação com o uso desse recurso cognitivo mencionando estratégias de articulação entre palavras e imagens que representam determinado objeto. Logo, nessa ordem discursiva, estão presentes algumas ideias relacionadas a "[...] ajudas audiovisuais, aulas dinâmicas e ensino técnico-profissional [...]" (FREIRE, 1982. p. 124). Além disso, identificamos algumas evidências enunciativas que reforçam a presença da "associação mnemônica" como possibilidade de "uso da imagem" nesse discurso. São elas: "[...] palavra geradora, representação gráfica da expressão oral [...] visualização da palavra geradora [...] vínculo semântico entre ela [a palavra] e o objeto a que se refere [...]” (FREIRE, 1967, p. 115).

A segunda possibilidade de uso é a "ilustrativa". Trata-se de conceber a imagem visual como estratégia didático-pedagógica de ilustração de situações ou noções a se problematizar no processo educativo. Nessa perspectiva, os usos da imagem aparecem como formas de "[...] ajudas audiovisuais, [favorecendo a realização de] aulas dinâmicas [...]” (FREIRE, 1982. p. 
124). Como exemplo desse tipo de estratégia, Freire (2009, p. 46) relata:

[...] A primeira página de Práticas para aprender é composta de duas codificações (duas fotografias): uma, de uma das lindas enseadas de São Tomé, com um grupo de jovens nadando; e a outra, numa área rural, com um grupo de jovens trabalhando. Ao lado da fotografia dos jovens nadando, está escrito: "É nadando que se aprende a nadar". Ao lado da fotografia dos jovens trabalhando, está escrito: "É trabalhando que se aprende a trabalhar". E, no fim da página: "Praticando, aprendemos a praticar melhor".

A terceira possibilidade de "uso da imagem" identificada é a de "mediação do conhecimento". Nessa ordem do discurso, a imagem é utilizada como estratégia de problematização de situações e experiências. É uma forma de se distanciar da situação codificada para questioná-la. Logo, com essa possibilidade de uso, a situação existencial assume o caráter de situação-problema. É mobilizando esse enunciado que Freire (1979, p. 70) relata o quanto "é impressionante ver como se travam os debates e com que curiosidade os analfabetos vão respondendo as questões contidas na situação codificada na imagem.” Em suma, trata-se de se utilizar a imagem como um artefato com o qual podemos acessar o conhecimento, determinado objeto ou uma aproximação da realidade. Portanto, "na [...] problematização da situação codificada, [...] pode-se alcançar a compreensão da 'estrutura profunda' da codificação, que abre possibilidades para análises críticas em torno da realidade codificada [...]" (FREIRE, 1982. p. 52).

O uso da imagem como ferramenta metodológica na alfabetização passa a ser um forte recurso de visualização da realidade, a fim de se ter mais riqueza de reflexões e problematizações da realidade. Ao longo desta discussão, vimos que Freire reconhece a importância das imagens veiculadas nos meios de comunicação, entre elas, a fotografia, o videotexto, a própria televisão etc., pois, quando utilizados criticamente no processo educativo, esses instrumentos podem proporcionar, sobretudo, uma tomada de consciência, um deslocamento da ingenuidade para a criticidade.

\section{ASSINALAÇÕES FINAIS}

Considerando o que tratamos aqui, vimos que "experiência" e "vivência" são noções correlatas à de mundo objetivo, quando recorrem ao primado da realidade como conceitoschave de sua produção. Esses conceitos-chave operativos funcionam, a um só tempo, como um critério de análise crítica e de validação das narrativas pronunciadas sobre o cotidiano, bem como parâmetro de escolha dos dispositivos investigativos que abordam os fatos 
ocorridos tal como aconteceram.

Como vimos, o procedimento assumido na construção da pronúncia do mundo, seja ele construído por quem viveu determinada experiência, por quem sistematizou metodicamente o vivido ou por quem dissertou sobre achados intencionalmente investigados ou casualmente encontrados, através de fontes documentais escritas, faladas ou visuais, evidencia um tipo de saber que visa, a seu modo, comunicar a realidade de tal modo que ela possa ser representada como a realidade que foi ou está sendo. O princípio da realidade exige que as coisas ditas e o saber que representam correspondam ao mundo fático.

Ressalte-se, entretanto, que se aceitamos a ideia de que nossa familiaridade com o mundo fático sugere um princípio de validação de sua realidade objetiva, não seria diferente a ideia de que também temos familiaridade com o mundo simbólico, imaginário, abstrato, sensível. Isso sugere, evidentemente, que reconheçamos a existência de uma realidade subjetiva, característica de outro mundo, onde o saber expressa não uma relação de correspondência entre as coisas ditas e os fatos, mas uma ligação simbólica e subjetiva entre o universo de significados, sentidos e valores, que são aceitos, atribuídos e vividos subjetivamente pelos indivíduos e pela coletividade, e o mundo objetivo das experiências fáticas, existenciais e históricas.

Com efeito, esse entendimento abre a possibilidade de vislumbrarmos outras dimensões da realidade humana, dos acontecimentos sociais e das práticas culturais, situados no território da linguagem, o qual aponta alternativas de ações concretas e de investigações socioculturais, centradas, prioritariamente, no par significante-significado, outras camadas a serem sitiadas, escavadas e escandidas, outros pressupostos e premissas teórico-metodológicos, outros objetos, problemas, hipóteses e achados a serem estudados, pesquisados e conhecidos e outros dispositivos e fontes de produção do saber epistêmico.

Se nossa atenção se desloca do texto-fonte em si e das coisas que ele registra, como, por exemplo, os significantes e os significados usados nas argumentações reflexivas e analíticas, e dos fragmentos, das palavras e das frases formuladas pelo autor; se nossa intencionalidade analítico-reflexiva se ocupa em investigar, nesse caso, a rede de enunciados que tece e faz emergir o aparecimento desses termos específicos e seus correspondentes significados, veremos que os dizeres freireanos contemplam outros objetos de investigação, situados em outra camada da análise, afeitos à existência de uma ordem específica de natureza discursiva, cujo saber vinculado regula o que se diz e se pode dizer, o que se afirma e se nega, o que deve ser ou não valorizado, marginalizado, desqualificado, silenciado e elidido sobre o nexo pedagógico entre educação e visualidade em seus escritos. 
Enfim, ratificamos que o propósito deste ensaio foi o de fazer um movimento analíticoargumentativo que partiu da realidade sugerida pela noção de experiência e deslocou-se para o campo da linguagem, proporcionado pela composição sígnica do par significante-significado, visando chegar ao nível do discurso, como um lugar que não é definido nem pelas palavras nem pelas coisas, mas pelo enunciado. Esse movimento nos permitiu vislumbrar a diferença qualitativa entre distintas alternativas de modos de conceber, de abordar e posicionar a questão da imagem visual em Freire e de situar e defender a Análise Arqueologia do Discurso como um caminho possível de investigação deste e de outros assuntos.

\title{
PAULO FREIRE AND THE PEDAGOGICAL USE OF VISUAL IMAGE IN LITERACY OF YOUTH AND ADULTS
}

\begin{abstract}
This test performs two functions. The first is to analyze the order of discourse that makes use of the image emerge in the literacy process present in the Freirean pedagogical proposal. The second, while working with the theoretical-methodological approach of the Archaeological Analysis of Discourse - AAD, proposed by Michel Foucault, seeks to affirm that the AAD is characterized as a possibility of investigation in the field of education and, specifically, of popular education. We find that the statement of the pedagogical use of the image appears in mentions about the genres of drawing, pictorial, photographic and audiovisual. The use of visual images is related to the notions of visual code, representation of the world and object of knowledge; And the functions mnemonic association, illustration and mediation of knowledge as pedagogical strategies of the literacy of young people and adults. The study points out, on the one hand, the theoretical and methodological pertinence of the DAF, on the other hand, that although Freire did not develop an elaborate discussion, the problem of the visual image has not ceased to be the object of its attention and use in educational practice.
\end{abstract}

Keywords: Youth and Adult Literacy; Visual Image; Archaeological Analysis of Speech

\section{PAULO FREIRE Y USO PEDAGÓGICO DE IMAGEN VISUAL EL ALFABETIZACIÓN DE JÓVENES Y ADULTOS}

\section{Resumen}


Essa prueba cumple dos funciones. La primera consiste en analizar el orden del discurso que pone de manifiesto el uso de la imagen en esse proceso de alfabetización en la propuesta educativa de Freire. El segundo, el tiempo que opera con el enfoque teórico y metodológico de análisis del discurso arqueológico - ADF, propuesto por Michel Foucault, decir que el ADF se caracteriza como una oportunidad de investigación en la educación $y$, en concreto, de la educación popular. Observamos que la imagen Declaración de uso pedagógico aparece en términos de los géneros de dibujo, gráfica, fotográfica y audiovisual. El uso de imágenes visuales a continuación, relacionados con las nociones de representación de código visual del mundo y el objeto del conocimiento; y las funciones de asociación mnemotécnicos, la ilustración y la mediación de conocimientos y estrategias pedagógicas de alfabetización de jóvenes y adultos. El estudio señala, por una parte, la relevancia teórica y metodológica de la AAD, el otro, a pesar de que Freire no ha desarrollado una elaborada discusión, el tema de la imagen visual no ha dejado de ser el objeto de su atención y su uso en la práctica educativa.

Palabras-clave: Alfabetización de Jóvenes y Adultos; Imagen Visual; Análisis del Discurso Arqueológico

\section{REFERÊNCIAS}

ALCÂNTARA, M. A. M.; CARLOS, E. J. Análise Arqueológica do Discurso: uma alternativa de investigação na Educação de Jovens e Adultos (EJA). Intersecções - Revista de Estudos sobre Práticas Discursivas e Textuais, Jundiaí/SP, v. 3, n. 5, p.59-73, nov. 2013. Semestral. Disponível em:

$<$ http://www.anchieta.br/unianchieta/revistas/interseccoes/pdf/Interseccoes_Ano_6_Numero_ 3.pdf>. Acesso em: $20 \mathrm{dez} .2013$.

CARLOS E. J. O discurso sobre a educação de jovens e adultos: uma possibilidade de análise na perspectiva foucaultiana. In: VASCONCELOS, J. G.; MAGALHÃES JR., A. G. (Orgs.). Um dispositivo chamado Foucault. Fortaleza, LCR, 2002. p. 99-112.

CARVALHO, Vicente Vitoriano Marques. As imagens no "Método Paulo Freire" na experiência de Angicos (RN) - 1963. In: Revista Educação em Questão, Natal, v. 21, n. 7, p. 98-115, set./dez. 2004.

CENTRO PAULO FREIRE ESTUDOS E PESQUISAS. Biografia: tempo de exílio. Disponível em:

$<$ http://www.paulofreire.org.br/asp/template.asp?secao=biografia\&sub=biografia2 $>$. Acesso em: 23 de Jan. de 2013. 
. Biografia: tempo de São Paulo. Disponível em:

$<$ http://www.paulofreire.org.br/asp/template.asp?secao=biografia\&sub=biografia3 $>$. Acesso em: 23 de jan. de 2013.

FOUCAULT, Michel. As Palavras e as Coisas: uma arqueologia das ciências humanas. Tradução de Salma Tannus Muchail. 8. ed. São Paulo: Martins Fontes, 1999.

. Arqueologia do Saber. Tradução de Luiz Felipe Beata Neves. 7. ed. Rio de Janeiro: Forense Universitária, 2008.

Linguagem e Literatura. In: MACHADO, Roberto. Foulcault, a filosofia e a literatura. 2. ed. Rio de Janeiro: Jorge Zahar Ed., 2001.

FREIRE, P.; DONALDO M. Alfabetização, leitura do mundo, leitura da palavra. Tradução de Lólio Lourenço de Oliveira. Rio de Janeiro: Paz e Terra, 1990.

FREIRE, P.; GUIMARÃES, S. Sobre Educação: (diálogos). 3. ed. São Paulo: Paz e Terra, 2003.

FREIRE, P.; NOGUEIRA, A. Que fazer: teoria e prática em Educação Popular. 11. ed. Petrópolis, RJ: Vozes, 2011.

FREIRE, Paulo. A importância do ato de ler: em três artigos que se completam. 22. ed. São Paulo: Cortez, 1988. 1982.

. Ação cultural para a liberdade e outros escritos. 8. ed. Rio de Janeiro: Paz e Terra,

. Cartas à Guiné-Bissau: registros de uma experiência em processo. 4. ed. Rio de Janeiro: Paz e Terra, 1978.

. Educação como prática da liberdade. Rio de Janeiro. Disponível em:

<forumeja.org.br>. Acesso em: 26 fev. 2012.

. Educação e mudança. 3. ed. Rio de Janeiro: Paz e Terra, 1979.

. Extensão ou comunicação? 7. ed. Rio de Janeiro: Paz e Terra, 1983.

Terra, 2011.

Pedagogia da Autonomia: saberes necessários a prática educativa. São Paulo, Paz e

PLATÃO. Crátilo. Tradução de Maria José Figueiredo. Lisboa: Instituto Piaget, 2001.

ROMAO, José Eustáquio. Paulo Freire e a imagem. In: Educação \& Linguagem, v. 13, n. 22, p. 77-97, jul.-dez. 2010.

SAUSSURE, F. de. Curso de Linguística Geral. 2. ed. São Paulo: Cultrix, 2006. 